\title{
Students Engagement and Development of Generic Skills in Gamified Hybrid Service-Learning Course
}

\author{
https://doi.org/10.3991/ijet.v16i24.27481 \\ Azizah Yusof ( $\left.{ }^{\bowtie}\right)$, Noor Azean Atan, Jamalludin Harun, Mohd. Shafie Rosli, \\ Umi Mastura Abd Majid \\ Universiti Teknologi Malaysia, Johor Bahru, Malaysia \\ azizah38@graduate.utm.my
}

\begin{abstract}
Hybrid Service-Learning, an emerging trend of combining co-curriculum course embedded with service-learning instructional strategies in online settings, has increasingly gained popularity, as many service-learning educators are moving into online platforms. The ongoing COVID-19 pandemic has accentuated its needs, thus forcing education systems worldwide to find alternatives to face-to-face instructions, one of them being Hybrid Service-Learning. This has prompted many researchers to attempt utilising gamification in online courses to increase students' engagement. The purpose of this research was to report a Gamified Hybrid Service-Learning (GAMYSEL) through students' level of engagement proposed by Schlechty, used as a data classification to compare students' scorings in their earning of points, badges, level and leaderboards. The results of the study indicated that, the students' levels of engagement were relatively high through Advocacy Hybrid-Service Learning approach, where majority of them achieved the Strategic Compliance and Optimal Engagement categories. The students' generic skills were further analysed with one-way repeated measures ANOVA and it was discovered that, GAMYSEL had positive impacts in developing these skills in five stages of service-learning. Both of these findings suggest that student's engagement and generic skills had a significant effect on students learning after the use of GAMYSEL.
\end{abstract}

Keywords-gamification, students' engagement, advocacy, hybrid servicelearning, generic skills

\section{Introduction}

Service-learning is one of the recognized instructional strategies, which connects learning with real world problems by conducting community services. It has been established as one of the ways for an effective experiential learning practice, while also nurturing students' generic skills [1]-[4]. Among the issues pertaining to conventional service-learning is providing assessments, especially in large classes, where for course instructors need to assess students' collaborative reflection, collaborative learning and progress-based learning outcomes [5]. In addressing the challenges faced in teaching 
large classes, instructors would utilize online tools which could foster instructor-student, student-student, student-content, and student-technology interactions, to reduce the feelings of isolation and disconnectedness which students often feel [6]-[8]. Hence, to connect large classrooms with on-site service, it is imperative to have continuous reflection activities, along with the service-learning course [9]. A reflection of tasks is needed for a meaningful reflection, as it is one of the critical components in servicelearning [1], [10], [11].

The benefits of integrating technologies in service-learning have been investigated in a number of studies [1], [11]-[13]. The current COVID-19 pandemic has forced education systems worldwide to find alternatives to face-to-face instructions. As a result, Hybrid Service-Learning has been selected for its potential advantages. In enhancing service-learning, various researchers have asserted the importance of integrating online learning in service-learning, as an alternative to the traditional service-learning, due to its flexibility, adaptability, utility and potential cost savings [4], [14]-[16]. Online learning platform has been playing a growing role in the academic field, as many online courses have been developed, along with online learning materials, e-assessment and online discussion. This is well in tandem with the objective of Malaysia Educational Development Plan 2015-2025 [17], stated in the ninth shift in realizing a globalised online learning, which makes it imperative for educators to integrate online technology in students learning process. The growth of online platform also takes in the form of electronic service-learning, or in other words, Hybrid Service-Learning, which could be potentially transformed students who are disengage in learning despite their geographical constraints by arming online learners with a powerful tool to promote community involvement [16]. Hybrid Service-Learning occurs when the service, the educational component, or both occur in an online setting.

The reason of integrating technologies in learning is not to entirely replace the faceto-face classroom, but to empower the learning process to a greater height in developing students' generic skills [1], [11]. Hybrid Service-Learning often requires the use of both synchronous and asynchronous technology, including online platform, virtual meeting, e-mails and social network services [4], [13]. One of the advantages in integrating technologies in service-learning is cost effectiveness when conducting a service-learning project remotely. This is made possible with reduced transportation costs, less or no meeting space requirements and nearly costless virtual meetings when Hybrid ServiceLearning is implemented [13].

As Hybrid Service-Learning is growing and evolving, however, it becomes more apparent that, the limitations for both Hybrid Service-Learning and online learning are similar, a perceived lack of interaction and engagement [8]. Other limitations include distance, time, access, and connectivity, rendering the practicality of carrying out team projects through synchronous and asynchronous methods a difficult task [11], [13].

Online learning platform has been playing a growing role in the academic field, as many online courses been developed, along with online learning materials, e-assessment and online discussion. In enhancing online learning, various researchers have asserted the need for utilising gamification [18], [19]. Despite quite a number of researches conducted to determine the effectiveness of using gamification in online platform, only a few were focused on gamified service-learning. Therefore, there has been 
a lack of parallel innovative development in the field of community engagement and learning through Hybrid Service-Learning that connects with real life experience and community service. In keeping with the current requirements and embracing the $21^{\text {st }}$ century learning, educators must design an innovative instructional design of teaching and learning that can engage students to transfer from concept of theory learned to practical or application to the real world. In developing students' employability skills, learning must go beyond the mastery of core subjects, and Hybrid Service-Learning is expected to create opportunities for them to apply knowledge into practices by evidently developing their critical thinking skills, problem solving skills or community awareness [20]. Hence, the design of online platforms with gamification elements should also support students' engagement and the development of their generic skill in a Gamified Hybrid Service-Learning. Through this implementation, the two main objectives of this study, namely, to determine the effect of integrating gamification in Hybrid Service-Learning on student engagement and to improve the way students are engaged in learning to develop their generic skills, could be achieved. This paper is an extension of our work presented in the proceedings of the International Conference on Industrial Engineering and Operations Management [4].

\section{Gamified hybrid service-learning online platform}

\subsection{Gamification in hybrid service leaning online platform}

The teaching and learning for undergraduates are conducted using a type III Hybrid Service-Learning model, where the instructions are given face-to-face, on-site and online [16]. In the online platform, the instructor holds a face-to-face teaching session using video conferencing tools with the inclusion of virtual meetings to facilitate students' online learnings. During these meetings with the community partners via conferencing tools, students are required to turn on their cameras, so that their facial expressions can be seen and eye-contacts can be made, while interviewing them in collecting data, akin to having face-to-face interactions. In a study by [21], virtual conferencing tools were the subjects of collaborating with partners and clients at remote sites. A physical meeting is one conducted by a physical attendance at a particular place, while a virtual meeting has the characteristic of being almost real in attending it, because the communication is experienced through nonverbal cues [22]. Thus, by keeping it really similar to a physical meeting, a face-to-face meeting, held virtually, enables people to synchronously meet together, when both sides switch on their cameras, while sharing together information in real time and in the same meeting room, without being physically present together. However, as similar as it can be with a physical meeting, it has disadvantages in terms of less social instincts among the meeting participants [22]. Therefore, to overcome this problem, gamification elements were integrated into it.

Gamification, which is the use of game design elements in educational context, namely, points, badges, levels and leaderboards has been proven to be an effective tool in getting students' attention, while making them more committed to a mission and positively influencing their behaviour [23]. In gamifying students' learning to make 
them more committed to complete the Computer Network Infrastructures Cabling project, the Gamified Hybrid Service-Learning (GAMYSEL) online platform was developed, using LearnDash plugins, installed in WordPress. WordPress, popularly known as a blogging site has upgraded its system that provides a variety of website types and a robust content-management system. The robustness is suitable for a non-technical user, since it can be used without coding skills. LearnDash was chosen because it supports GamiPress as additional plugins for integrating gamification elements, namely, points, badges, level and leaderboards, to provide learning activities that are engaging to the service-learning students. As for the teaching and learning purpose, the LearnDash platform provides learning tools, such as online storage materials, video learning progression, advanced quizzes, and assignment submission that suit the needs of the researcher to organize the learning activities which meet the service-learning ambiance. LearnDash also has a feature, where users can view their earning in points, badges, level and leaderboards from their profile. Without this feature, all feedback and submissions for the learning tasks created in GamiPress would need to be manually graded for users to receive their earnings.

Besides, BuddyBoss plugin was added as additional plugins because it allows blogging, forum discussion and groupings features, which are crucial for the students' learning experience. The blogging and forum discussion features allow users to reflect on what they have learned. For instance, by using blogging features, users can write in their e-portfolio reflection. Meanwhile, the forum discussion allows users to initiate a discussion with their peers and reflect on their learning. BuddyBoss plugin also allows users to create groupings for students to collaborate in teams. On top of that, it features a theme that is similar to Facebook and is thus suitable for the Z-generation to easily familiarise with the online platform. Figure 1 shows a screenshot example of the interface viewed from Firefox browser. The online course subject "ICT for Community Services" was designed by the instructor for the purpose of undergraduate students' teaching and learning, while the online course subject "Introduction to Cabling Network Infrastructure" was designed by the ICT Team Committee for facilitating the community involved in the project. The menu bar is for users to easily access and navigate the page. Each menu directs the users to another page and icon on the left pane gives alternatives for them to have a quick access. For example, the icon cloud conversational represents the forum discussion, icon mobile phone represents chatting and the icon three people represents creating groups.

To suit service-learning ambience, GAMYSEL encourages students to collaborate with community of experts and locality-based community who form the integral parts of learning expeditions. The instructor of the course selected and partnered with community of experts in the field to engage on students' projects, taught them skills from their field and critiqued their work using professional standards. The partnership was aimed to address the community needs and serve the communities by "strengthening the economic development of the region, addressing educational and health needs of the community, and contributing to the cultural life of the community." [24]. In gamifying the learning process, students were given badges for every work collaboration with the community of experts and addressing community needs in terms of the students' thinking skills, scholarship, adaptability skills, teamwork skills, 
communication skills and global citizenship. The collaboration with community of experts with particular disciplines on the field of students' venture in addressing community needs was made to ensure integrity, accuracy and quality in the servicelearning project. And students together with experts and school community collaborate together to solve problems encountered at school by providing community service activities.

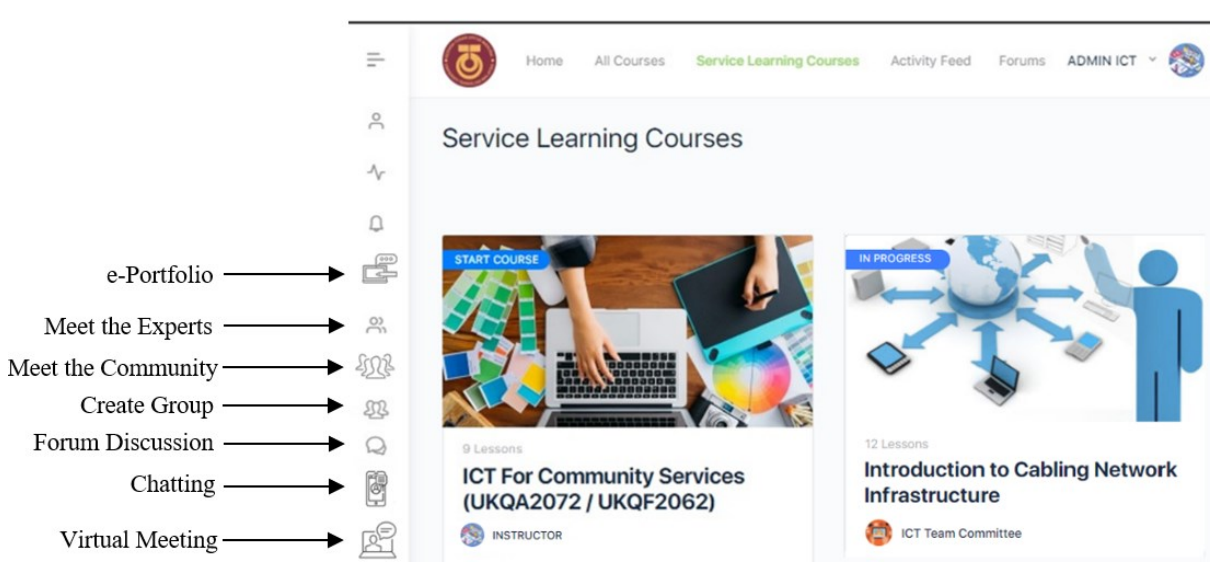

Fig. 1. Interface viewed from Firefox Browser

In preparation and planning for the service-learning project, students were required to discuss in virtual meetings, write meeting minutes and track progress project milestone from the Gantt Chart discussed. Group work and group meetings are beneficial for students development and employability skills so that they can thrive in the Fourth Industrial Revolution, and these skills include people management, coordination with other people and service orientation [25]. In the various virtual meetings, students were to summarise their discussion and inform their progress in the forum discussion for their reflective learning. For every post discussion and reply, students were able to earn points. GAMYSEL also supports peer collaborations by allowing team members to create groups. These peer collaborations have created an active learning environment for students to have further discussions on certain topics in smaller groups and earn even more points and badges.

Simultaneously, chatting integration in GAMYSEL supports peer and community collaborations by introducing mobile devices to learning activities. Figure 2 shows the interface viewed from the mobile devices. The auto-fit page for users accessing the learning content via mobile devices allows a more user friendly and mobile learning.

The mobile learning enables learning activities outside the classroom to take place anytime and anywhere, as long as the internet access is available [26]. The role of mobile learning in service-learning context is to allow learners connect with the physical environment and place learning in authentic contexts, for example interactions with the community during site visits. In this way, students are able to engage with the learning materials in a real-world context. Gamifying the learning material is accomplished by 
providing levels for each topic learned with the purpose for students to see their learning progress. Students are required to complete tasks before going to the next level. Students are able to see their stands among their peers in the leaderboards position at each level. Finally, by having a gamified service-learning environment, students are able to write their e-portfolio to reflect and houses their accomplishments, projects, experiences and interests with a more organized structure. Service-learning students writing their e-portfolio entry are required to compile and organise their work by using different types of media, including text, photo, sound clips, video clips, animation, hyperlink and others [4].

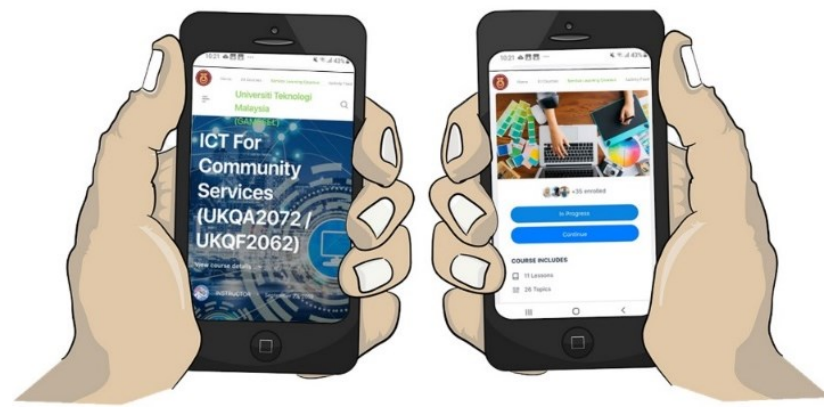

Fig. 2. Interface viewed from a mobile device

\subsection{Gamification in advocacy hybrid service-learning project}

For students to reflect on their learning, an Advocacy Service-Learning approach was utilised, as a service, which provides a means in educating the community about computer network infrastructure, so that, they will have the knowledge and skills required to design computer network infrastructure and to do maintenance for the school community which have poor cabling infrastructure. Experts in IT Network were invited by the instructors to collaborate with students in the project. Students were asked to become committee members and to take roles in the management team. The team worked together by planning and designing a computer network infrastructure for a school building with a poor cabling infrastructure. In planning to advocate a computer network infrastructure, UTM students collaborate with IT network experts to learn from professional in conducting cabling infrastructure. Figure 3 shows how community partners are involved in Advocacy Hybrid Service-Learning project.

In this project, the team members brainstorming together with IT experts from Telekom Malaysia in solving problem in school building with a poor cabling infrastructure. The project involved local participants, namely, school students, school teachers, and school administrator working together with UTM students team member. Other than team member meeting remotely with the school community via virtual meet, the team members provide an online course to ensure the school community have the basic knowledge of cabling infrastructure. This is also to ensure the service-learning project would run smoothly, and school community able to sustain the school cabling infrastructure on their own. 


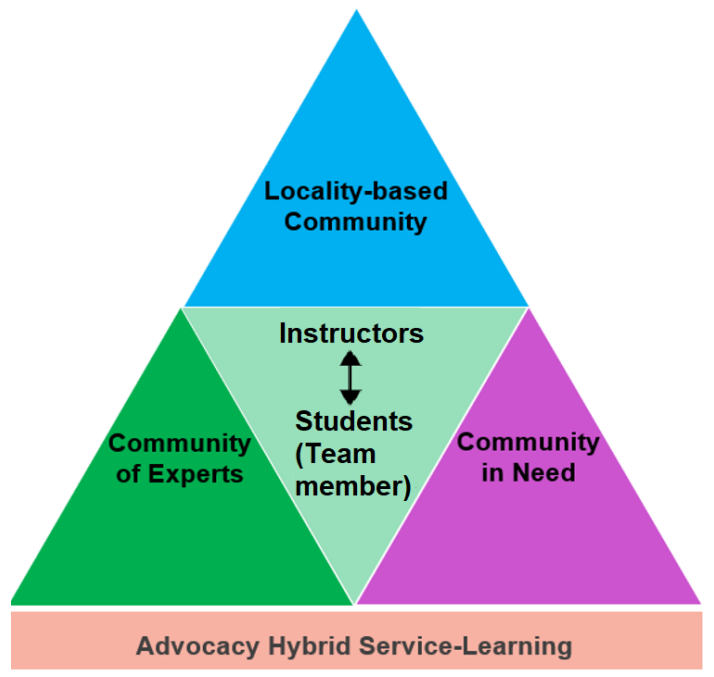

Fig. 3. Involvement of Community Partners in Advocacy Hybrid Service-Learning Project

To ensure transfer of knowledge and skills occurs to the school community effectively, students took the initiative in creating an online course titled, "Introduction to Cabling Network Infrastructure" for the school community teaching and learning. The online course was learned by school community including, school principal, school teachers, and school students anytime and anywhere, as long as the internet access is available. By providing an online course, the school community would have a longterm benefit in understanding the cabling infrastructure and provide appropriate maintenance by themselves in future.

By strengthening online learning with the community by teaching each other, sharing knowledge and contribute to the community, students are able to reflect on their learning. By reflective learning, students are able to become an active learner when they write down their thoughts, ideas and express their learning experience [27][28], [29]. However, previous research have shown students felt compelled in writing assignments or tasks given to them as they view of having no intrinsic meaning [30], [31]. Hence, to encourage students to reflect on their learning especially in an online learning environment that have occurrence of less social instinct, gamification elements including badges, levels, leaderboards and points was integrated. The gamification elements were designed as a reward system base implemented in community service project to foster engagement and drive learners' retention. In this way, students can reflect on their learning and serve better the community in organize manner. The on-site service project implementation, carried out in small groups comprising IT Network experts and school community, took three days to complete. In compliance with the COVID-19 Standards Operating Procedure, the practical work in the Advocacy Hybrid ServiceLearning project was done while maintaining physical distance and wearing personal protective equipment, including face masks and hand gloves, throughout the project. In general, GAMYSEL provides opportunities for students to be more committed in their collaborations with community of experts and participants from the school community 
to complete the Advocacy Hybrid Service-Learning project in addressing the needs of the society. This form of experiential education, in which students engage in activities which address human and community needs has structured opportunities for reflections designed to achieve desired learning outcomes [32].

\section{$3 \quad$ Engagement and generic skills}

\subsection{GAMYSEL for students' engagement}

Engagement, according to [33] refers to the behavioural component that relates with the amount of physical and psychological involvement towards students' learning experience. Specifically, engagement in academic is defined by [34] as "the student's psychological investment in an effort directed toward learning, understanding, or mastering the knowledge, skills, or crafts that academic work is intended to promote". According to [35], gamification can shape behaviour, develop cognitive skills, support collaboration, and increase user engagement. For [36], students' engagement is an effort of students to put forth the task with persistency and committed to voluntarily performing the task despite having the tasks to be boring, humdrum, and routine.

As discussed in the previous paragraph, suggested that, students using the online platform should retain information and be more behaviourally involved while having the habit of volunteering in the learning experience. Students are likely to be involved when they are participating, interacting, giving attention, on-task, persistent and diligent towards the learning process [37], [38]. By this proposition, giving feedback is one of the essential elements in implementing gamification, because students need to ensure their right path of learning [39], [40]. By implementing feedback facilities, technologybased activities provide interaction for students engagement in learning [41].

As previously stated, feedbacks in the form of points, badges, level and leaderboards are one of the most common fun-like gamification elements infused in a gamified learning environment for a non-game context [23], [39], [40], [42], [43]. Affirmation feedback in the form of fun would encourage students to focus attention in learning [36]. Hence, giving rewards for actions taken, including accumulated points and earned badges, opportunities to see their progress and to see their stands among their peers provides a learning environment experience for the students to actively participate and interact, in their learning process. The rewards system base also creates an environment for users to have their achievements acknowledged by complimenting them with the redemption of rewards, thus would increase learners' social instincts in online learning environment. The redemption of points and badges is similar to a non-game business to increase engagement by customer participating in a loyalty programme in order to generate higher returns. Gamification implemented in customer loyalty programmes is effective to engage customer and drive customer retention [44], [45].

Similarly, for the purpose of this study, gamification elements use a reward system base implemented in a real-world context to foster engagement and drive learners' retention in regard to the learning activities involved. Because the GAMYSEL utilise reward system, it relates much with students' retention in their involvement in learning 
activities which form a linkage with behavioural engagement, which includes willingness to participate [46], [47] and their involvement in completing given tasks [48]. The learners' engagement has been considered as a different continuum degree of engagement, from rebellion to optimal engagement, as the students' involvement in the learning activities. Table 1 shows students' level of engagement adapted from Schlechty (2011) and its respective indicator.

Table 1. Students' Level of Engagement and Its Respective Indicator (Adapted from [36])

\begin{tabular}{|l|l|}
\hline Students' Level of Engagement & \multicolumn{1}{|c|}{ Engagement Indicator } \\
\hline Optimal Engagement [OE] & $\begin{array}{l}\text { The application of gamification elements into the tasks, activities, or } \\
\text { work has clear meanings and immediate values to participants. }\end{array}$ \\
\hline Strategic Compliance [SC] & $\begin{array}{l}\text { The application of gamification elements into work has little meanings } \\
\text { or values to participants, but extrinsic results are valuable to partici- } \\
\text { pants. }\end{array}$ \\
\hline Ritual Compliance [RC] & $\begin{array}{l}\text { Participants are willing to complete the gamified work to avoid nega- } \\
\text { tive consequences, even though meanings are not present. }\end{array}$ \\
\hline $\begin{array}{l}\text { Retreatism } \\
{[\mathrm{RT}]}\end{array}$ & $\begin{array}{l}\text { Disengagement from gamified task; little to no energy present, but no } \\
\text { disruption caused to others. }\end{array}$ \\
\hline $\begin{array}{l}\text { Rebellion } \\
{[\mathrm{RB}]}\end{array}$ & $\begin{array}{l}\text { Refusal to complete the gamified task, disruptions caused to others and } \\
\text { completion of task avoided with substitute actions. }\end{array}$ \\
\hline
\end{tabular}

Learners' engagement is their willingness to participate in the learning activities and their effort to complete time-on-task activities [49]. Student engagement, according to [50], is believed to be one of the predictors of learning achievement and generic skills development. The more added values in students' knowledge and their involvement in the learning activities, the more they construct their own knowledge. As a result, students' behavioural involvement in learning activities had an effect on their cognitive engagement as well. This reflects on the study by [51], which results indicate a positive correlation between behaviour engagement and learning outcomes with higher test scores and better performance in course work, to compare with emotional engagement which shows a negative correlation on students' performance. This comparison indicates that, the affective state of valence, arousal, and positive endurance may not always translate into better performance, and behavioural engagement should be taken into account, so that the success of a learning process can be measured.

\subsection{GAMYSEL for students' generic skills}

Researchers have all agreed that, behavioural engagement is a multifaceted behaviour that can be seen in students' physical activities, including effort, persistence, participation and others [37], [38]. Academic behaviours reflect the amount of efforts a student decides to his psychological investment in his learning process [52]. This decision is influenced by the most basic and foundational tools for achieving a social behavioural change, namely, civic engagement [53]. Community skills are one of the common elements of generic skills in civic engagement or citizenship knowledge and skills [54]. Service-learning and civic engagement can provide "a means for reaching 
and enhancing the most fundamental purpose of educating their constituencies and fulfilling their mission in ways that benefit the greater society, produce a more civil society, and strengthen democracy" [55] p.202.

Interest in service-learning has been growing among institutions of higher education in Malaysia and many are combining co-curriculum course embedded with servicelearning instructional strategies in online settings. Hence, many co-curriculum courses are now labelled with SULAM designation, referring to Service-learning Malaysia, University for Society. SULAM, launched in April 2019 [56] is defined as "learning methods that combine learning objectives with community service to provide a progressive learning experience by solving real problems in the community, based on love, happiness and mutual respect" [57]. Figure 4 illustrates the model of SULAM adapted from [57] and [58].

The establishment of SULAM emphasises the accomplishment of tasks to meet human and community needs, based on students' generic skills development in leveraging service-learning pedagogy, in ensuring effective course learning outcomes. Servicelearning from this perspective recognises the benefits of community service to students and to the community. The benefit of service-learning is that, it connects student learning in the classroom with real-world experiences in the community [59], encouraging them to be more deeply engaged in their local communities, gain practical skills, and develop their career.

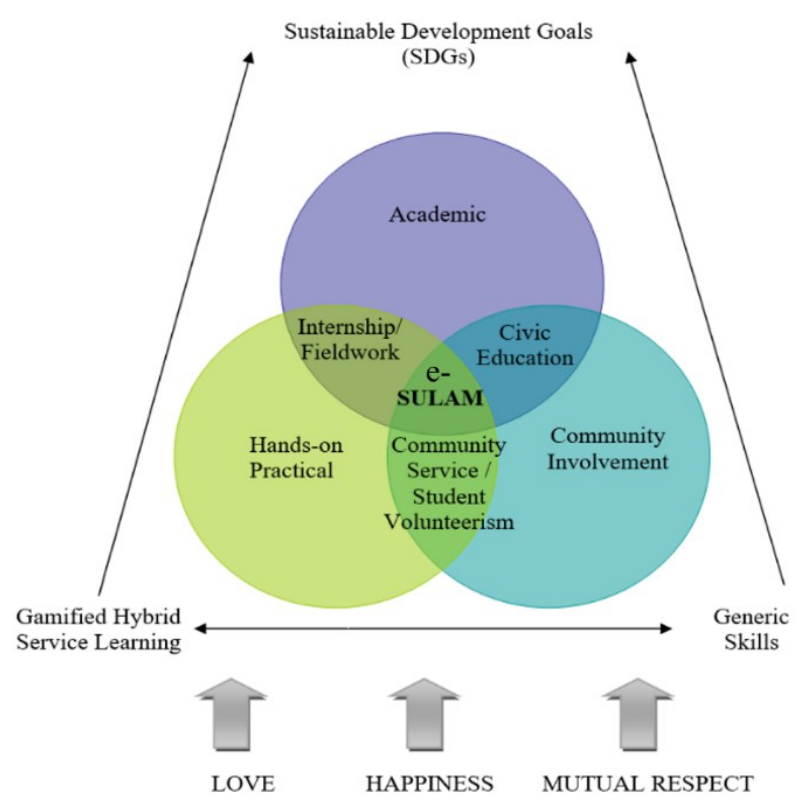

Fig. 4. Model of Achieving Sustainable Development Goals in e-SULAM

At a societal level, it is important for students to be involved and aware of their communities, so they can assist each other and become more conscientious individuals [60]. Hence, it instils the habit of performing a service for others and consequently 
entails the possibilities to meet the fourth, eighth and tenth goals of Sustainable Development Goal, namely, Quality Education, Decent work and Economic Growth, and Reduced Inequalities [61]. In associating with inequitable knowledge transfers among undergraduate students and the community in need involved, it has given the opportunity to develop students' employability skills. Therefore, there is a need to implement a learning approach that contributes to the success of graduate students to be ready for their future workplace. Generic academic learning objectives include knowledge and skills that are learned and are instrumental for service-learning courses.

Table 2 is a summary of students' generic skills elements, assessed during this study and their definitions. The students' generic skills are coded as Thinking Skills (TH), Scholarship (SC), Adaptability Skills (AD), Teamwork Skills (TW), Communication Skills (CM) and Global Citizen (GC) [62]. In strengthening the $21^{\text {st }}$ century skills for quality education, researchers have suggested that, learning in an online environment can facilitate service-learning which transforms learning while promoting employability skills [1], [4], [16]. GAMYSEL contributes in such a way that, online learning activities and online course designed are delivered in Advocacy Service-Learning approach, which can add values and increase effectiveness of Hybrid Service-Learning. The five stages of service-learning, namely, investigation, preparation and planning, action, reflection and demonstration constitute the effectiveness of knowledge and transferable skills among students [4], [59].

Table 2. Students Generic Skills and Definitions

\begin{tabular}{|l|c|c|c|}
\hline \multicolumn{1}{|c|}{ Elements } & Generic Skills & Code & Definition \\
\hline \multirow{2}{*}{$\begin{array}{l}\text { Conceptual/Thinking } \\
\text { Skills }\end{array}$} & Thinking Skills & TH & Ability to expand on and discuss ideas. \\
\cline { 2 - 4 } & Scholarship & SC & $\begin{array}{c}\text { Ability to seek and manage relevant information from } \\
\text { a variety of sources. }\end{array}$ \\
\hline $\begin{array}{l}\text { Personal Skills and At- } \\
\text { tributes }\end{array}$ & Adaptability Skills & AD & $\begin{array}{c}\text { Ability to adapt and act ethically to the culture of new } \\
\text { communities and work environment. }\end{array}$ \\
\hline People Related Skills & Teamwork Skills & TW & $\begin{array}{c}\text { Ability to establish rapport, interact and work effec- } \\
\text { tively with others to accomplish common objectives. }\end{array}$ \\
\cline { 2 - 4 } Communication & Skills & CM & $\begin{array}{c}\text { Ability to convey ideas in writing clearly, effectively } \\
\text { and comprehensibly. }\end{array}$ \\
\hline Community Skills & Global Citizen & GC & $\begin{array}{c}\text { Ability to interact with the community, act profession- } \\
\text { ally and responsibly in carrying out duties. }\end{array}$ \\
\hline
\end{tabular}

The emerging trends of gamification have gained the benefits from the use of this technology to engage in real world activities. GAMYSEL has included an element of constructivism, including asynchronous discussion, synchronous discussion, work collaboration, virtual meetings and e-portfolio writings to encourage students to reflect on connections between community needs, academic courses and employability skills. In this practice, gamification integration provides students the opportunity to construct knowledge by interacting to accumulate points, earn badges, to achieve and compete among their peers, so that they can perform well in the service-learning project. This blended approach in exploring generic skills in higher education allows the researcher to explore the notion of generic academic learning in this study, from four different elements of generic skills, in the forms of conceptual/thinking skills, personal skills and 
attributes, people related skills and community skills. This is followed by enhancing student learning by considering the advantages of integrating GAMYSEL for students' engagement.

\section{$4 \quad$ Research design}

In this study, students' engagement was considered as their behavioural involvement in the learning activity, where gamification elements, namely points, badges, level and leaderboards were utilised to evaluate the intervention of GAMYSEL on their learning engagement and the development of generic skills.

\subsection{Respondents of ICT for community services in GAMYSEL}

ICT for Community Services is a co-curriculum course for undergraduate students, where students relate Information Communication Technology (ICT) field with community engagement. The co-curriculum course is one of the compulsory courses for students to complete their undergraduate studies. The respondents were from various faculties and departments, with different levels of academic backgrounds, enrolled in this elective course. The students were engaged in a semester-long Computer Network Infrastructures Cabling project, during which, they needed to complete several online discussions, assignment submission, e-portfolio writings and were assigned with weekly group discussion. The students also had to complete their final project with selected experts and participants from school community. The course integrates a gamified e-service-learning model design of hybrid type III, a gamified blended format with instructions and Advocacy Service-Learning approach, partially online and partially on site.

\subsection{Quasi experimental}

The quasi-experimental section of the course was redesigned to utilise GAMYSEL online platform. To examine the effectiveness of GAMYSEL on student engagement towards their generic skills, a quasi-experimental design was implemented with the use of a time series design. Because of the non-random learning activities to the respondents in the quasi-experimental exercise, a pre-test was implemented at the beginning of the exercise, followed by several repetitions of assessments, before a post-test was given to the students.

\subsection{One-way repeated measures ANOVA}

The repeated learning activity was to assess changes in student engagement towards GAMYSEL and the development in their generic skills. This design is characterised by multiple observations, over 14 weeks, involving the same participants to record differ- 
ences attributed to some given treatments. In the One-way ANOVA Time-Series design, a treatment was introduced at each service-learning stage in the series of observations, and this design is schematically shown in Figure 5.

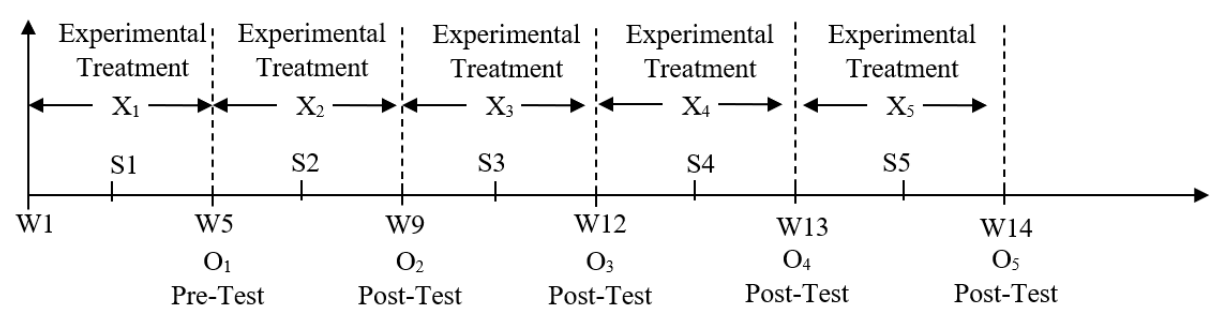

Fig. 5. Pattern design for time series design in the quasi-experimental method

An "X" represents the exposure of a group to an experimental treatment, while an "O" signifies a type of observation or measurement conducted, and a "W" represents the time interval in weeks. The interrupted time series design was observed in five stages of service-learning stages, namely, "S1" representing Stage 1: Investigation, "S2" representing Stage 2: Planning \& Preparation, "S3" representing Stage 3: Project Implementation, "S4" representing Stage 4: Reflection and lastly "S5" representing Stage 5: Demonstration.

\section{$5 \quad$ Method}

The study used an interpretive, mixed method approach which provides an in-depth finding and it binds together the strengths of both quantitative and qualitative approaches. This method offers its advantages in terms of the processes, interactions and more concrete explanation to a situation, to provide a better understanding for the context of a study [63]. A hybrid service-learning classroom of 30 students from the course ICT for Community Services was involved in this particular study. The research procedure in this study was treated as part of the teaching and learning process. All the information and data collection process went on smoothly and as planned. The students' learning activities were administered for 14 weeks for data analysis purposes, according to One-Way ANOVA with Time Series Design in five stages of service-learning. Purposive sampling was used in this research, targeting the undergraduate students from various fields, enrolled in elective subjects offered.

\section{Data collection and analysis}

The data was generated from students' log file and analysed using Statistical Package for the Social Sciences (SPSS) v28 for analysing, descriptively. The analysis was divided into two parts, the first part was to evaluate the effects of students' learning activities with a GAMYSEL online platform on their engagement and the second part was to evaluate their generic skills. 


\subsection{Analysis on the effect of GAMYSEL on students' engagement}

The data was analysed descriptively and was measured by students' earnings of gamification elements in the forms of points, badges, level and leaderboards. The comparisons of students' scorings in earnings of points, badges, levels and leaderboards were classified into Schlechty's Levels of Student Engagement [36] and clustered into benchmark points, benchmark badges, benchmark levels and benchmark leaderboards, respectively, as shown in Table 3. The total benchmark scoring of students' earnings was further categorised into each of these criteria, namely Rebellion [RB], Retreatism [RT], Ritual Compliance [RC], Strategic Compliance [SC] and Optimal Engagement [OE]. Table 4 summarises the students' level of engagement, based on points, badges, levels and leaderboards. From the table, it can be observed that, majority of the students were most of the time engaged with the gamification elements while learning using the GAMYSEL online platform, proven with Optimal Engagement and Strategic Compliance were the dominant modes of response, as explained by [36].

Table 3. Levels of Engagement

\begin{tabular}{|c|c|c|c|c|c|c|c|c|c|}
\hline 竞 & 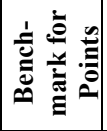 & 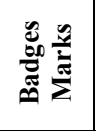 & 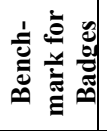 & 总范 & 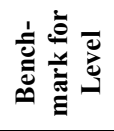 & 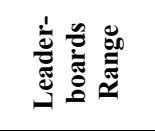 & 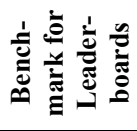 & 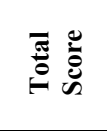 & 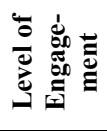 \\
\hline $121-150$ & 5 & $13-15$ & 5 & 5 & 5 & Top $1-6$ & 5 & $81-100$ & $\mathrm{OE}$ \\
\hline $91-120$ & 4 & $10-12$ & 4 & 4 & 4 & Top $7-12$ & 4 & $61-80$ & $\mathrm{SC}$ \\
\hline $61-90$ & 3 & $7-9$ & 3 & 3 & 3 & Top $13-18$ & 3 & $41-60$ & $\mathrm{RC}$ \\
\hline $31-60$ & 2 & $4-6$ & 2 & 2 & 2 & Top $19-24$ & 2 & $21-40$ & RT \\
\hline $1-30$ & 1 & $1-3$ & 1 & 1 & 1 & Top $25-30$ & 1 & $1-20$ & $\mathrm{RB}$ \\
\hline
\end{tabular}

Table 4. Summary of Students' Benchmark Scores

\begin{tabular}{|l|c|c|c|c|}
\hline \multicolumn{1}{|c|}{ Level of Engagement } & Points & Badges & Levels & Leaderboards \\
\hline OE & 7 & 24 & 27 & 11 \\
\hline SC & 14 & 4 & 3 & 7 \\
\hline RC & 6 & 2 & 0 & 6 \\
\hline RT & 3 & 0 & 0 & 2 \\
\hline RB & 0 & 0 & 0 & 4 \\
\hline Total & 30 & 30 & 30 & 30 \\
\hline
\end{tabular}

Table 5 is a summary of the total scores of earning points, badges, levels and leaderboards. From the table, the data revealed that, most students attained the $\mathrm{OE}=16$, this is followed by $\mathrm{SC}=10$ and only a minority of them attained $\mathrm{RC}=4$. The results revealed that, after using GAMYSEL, students' level of engagement was high, proven with the majority of them were in the category of Optimal Engagement and Strategic Compliance, as explained by [36]. 
Paper-Students Engagement and Development of Generic Skills in Gamified Hybrid Service-Learning...

Table 5. Summarisation of Students Benchmark Scores and Level of Engagement

\begin{tabular}{|l|c|c|}
\hline \multicolumn{1}{|c|}{ Benchmark Score } & Level of Engagement & Number of Students \\
\hline $81-100$ & OE & 16 \\
\hline $61-80$ & SC & 10 \\
\hline $41-60$ & RC & 4 \\
\hline $21-40$ & RT & 0 \\
\hline $1-20$ & RB & 0 \\
\hline & TOTAL & 30 \\
\hline
\end{tabular}

Table 6 displays comparisons of students' earnings of points, badges, levels and leaderboards. Based on the descriptive table, students were engaged more in levels having the highest mean, $\overline{\mathrm{x}}=4.87$, compared to other gamification elements. Overall, based on the findings gathered, all undergraduate students involved in this study had high engagements in their learning, with an overall mean, $\overline{\mathrm{x}}=4.23$ and a standard deviation, $\sigma=0.86$. This information serves as an overview for the researcher in identifying student's engagements in GAMYSEL.

Table 6. Statistical Data of Points, Badge, Leaderboards and Level

\begin{tabular}{|l|c|c|c|c|}
\hline \multicolumn{1}{|c|}{ Gamification Elements } & Mean & Std. Deviation & Minimum & Maximum \\
\hline Points & 4.0000 & 1.01710 & 2.00 & 5.00 \\
\hline Badges & 4.7333 & .58329 & 3.00 & 5.00 \\
\hline Levels & 4.8667 & .34575 & 4.00 & 5.00 \\
\hline Leaderboards & 3.3333 & 1.49328 & 1.00 & 5.00 \\
\hline Overall & 4.23 & 0.86 & & \\
\hline
\end{tabular}

\subsection{Analysis on the effects of GAMYSEL on students' generic skills}

The analysis was further examined using rubric form to analyse the effects of learning activities towards their generic skills with the GAMYSEL online platform. Students' generic skills were analysed in five stages, namely investigation, planning and preparation, project implementation, reflection and demonstration. The students' learning activities were administered for 14 weeks for their generic skills rubrics to be analysed on their engagement with points, badges, level and leaderboards. Table 7 illustrates the students' rubrics mark on each stage of their service-learning. Overall, the average marks of students' generic skills achieved throughout the semester was $81 \%$. During the Stage 1 (Investigation), the students' generic skills, in terms of Adaptability Skills (Pre-AD), Thinking Skills (Pre-TH), Scholarship (Pre-SC) and Teamwork Skills (Pre-TW), were evaluated. During this stage, they were administered from week 1 until week 4. Meanwhile, during Stage 2 (Planning and Preparation), the students' generic skills, in terms of Communication Skills (Pre-CM), Thinking Skills (Post-TH1), Scholarship (Post-SC1) and Teamwork (Post-TW1), were administered from week 5 until week 8. Following this, during Stage 3 (Project Implementation), the students' generic 
skills, in terms of Global Citizen (Pre-GC), Adaptability Skills (Post-AD1) and Thinking Skills (Post-TH2), were administered from week 9 until week 11. Subsequently, during Stage 4 (Reflection), their generic skills, in terms of Global Citizen (Post-GC1), Communication Skills (Post-CM1) and Scholarship (Post-SC2), were assessed in week 12. Finally, during Stage 5 (Demonstration), the students' generic skills, in terms of Communication skills (Post-CM2), Global Citizen (Post-GC2), Teamwork skills (PostTW2) and Adaptability skills (Post-AD2), were assessed from week 13 until week 14.

At each stage, students' generic skills were assessed to observe their generic skills development from GAMYSEL. As shown in Table 7, the mean score values of the students' generic skills assessments for all the stages are 13.53, 17.07, 16.47, 16.37 and 17.53 , for stage 1 , stage 2 , stage 3 , stage 4 and stage 5 , respectively. It can be seen that there is an increase of mean at the final stages, the use of GAMYSEL in teaching and learning was effective in developing students' generic skills.

Table 7. Students' Generic Skills Mean Scores from each Stage

\begin{tabular}{|c|c|c|c|c|c|c|}
\hline \multirow[b]{2}{*}{ 竞 } & $\begin{array}{c}\text { Weeks } 1 \text { - } 4 \\
\text { STAGE } 1\end{array}$ & $\begin{array}{c}\text { Weeks 5 - 8 } \\
\text { STAGE } 2\end{array}$ & $\begin{array}{c}\text { Weeks 9-11 } \\
\text { STAGE } 3\end{array}$ & $\begin{array}{c}\text { Week } 12 \\
\text { STAGE } 4\end{array}$ & $\begin{array}{c}\text { Weeks } 13-14 \\
\text { STAGE } 5\end{array}$ & \multirow{2}{*}{ 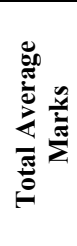 } \\
\hline & $\begin{array}{c}\text { Pre-AD } \\
\text { Pre-TH } \\
\text { Pre-SC } \\
\text { Pre-TW } \\
\text { (20 marks) }\end{array}$ & $\begin{array}{l}\text { Pre-CM } \\
\text { Post-TH1 } \\
\text { Post-SC1 } \\
\text { Post-TW1 } \\
\text { (20 marks) }\end{array}$ & $\begin{array}{c}\text { Pre-GC } \\
\text { Post-AD1 } \\
\text { Post-TH2 } \\
\text { (20 marks) }\end{array}$ & $\begin{array}{c}\text { Post-GC1 } \\
\text { Post-CM1 } \\
\text { Post-SC2 } \\
\text { (20 marks) }\end{array}$ & $\begin{array}{l}\text { Post-CM2 } \\
\text { Post-GC2 } \\
\text { Post-TW2 } \\
\text { Post-AD2 } \\
\text { (20 marks) }\end{array}$ & \\
\hline Mean & 13.53 & 17.07 & 16.47 & 16.37 & 17.53 & \multirow[b]{2}{*}{80.97} \\
\hline $\begin{array}{l}\text { Standard } \\
\text { deviation }\end{array}$ & 1.59 & 2.96 & 1.55 & 1.30 & 2.22 & \\
\hline
\end{tabular}

$* \mathrm{~N}=30$

To see the changes in students' generic skills development in GAMYSEL, a oneway repeated measure analysis of variance (ANOVA) was conducted to evaluate the null hypothesis that there is no change in participants' generic skills when measured before, during and after participations in the intervention. The results of Mauchly's Test of Sphericity were found to be significant ( $\mathrm{p} \leq 0.05$ ), as shown in Table 8, suggesting that, the assumption of sphericity was violated in multiple of treatments conducted. The degrees of freedom were adjusted using Greenhouse-Geisser correction for the new $\mathrm{df}$ value (0.598), based on which, it was clear that there was a significant difference in assessment scores in view of the students' generic skills development, F $(2.39,69.41)=$ $28.15, \mathrm{p} \leq, 0.05$ in all five stages in generic skills assessments.

Table 8. Mauchly's Test of Sphericity for Students' Generic Skills Assessments

\begin{tabular}{|c|c|c|c|c|c|c|c|}
\hline $\begin{array}{c}\text { Within Subjects } \\
\text { Effect }\end{array}$ & Mauchly's W & $\begin{array}{c}\text { Approx. } \\
\text { Chi-Square }\end{array}$ & df & Sig. & $\begin{array}{c}\text { Greenhouse- } \\
\text { Geisser }\end{array}$ & Huynh-Feldt & Lower-bound \\
\hline Generic Skills & .150 & 51.992 & 9 & $<.001$ & .598 & .656 & .250 \\
\hline
\end{tabular}

The results of the ANOVA indicated a significant time effect, Wilks' Lambda 0.086, $\mathrm{F}(2,28)=68.93, \mathrm{p} \leq 0.01, \mathrm{y}^{2}=0.91$. With regard to Pairwise Comparisons based on 
estimated marginal means for assessments in students' generic skills shown in Table 9 indicated that, there were significant different scores in generic skills before and after intervention only, but not in between, suggesting that, the participation in the intervention group only increased participants' level of generic skills in a longer period being in that group.

Table 9. Analysis of Estimated Marginal Means for Assessments on Students' Generic Skills

\begin{tabular}{|l|c|c|c|c|}
\hline \multirow{2}{*}{ Generic Skills } & \multirow{2}{*}{ Mean } & \multirow{2}{*}{ Std. Error } & \multicolumn{2}{|c|}{ 95\% Confidence Interval } \\
\cline { 4 - 5 } & & & Lower Bound & Upper Bound \\
\hline 1 & 13.533 & .291 & 12.939 & 14.128 \\
\hline 2 & 17.067 & .540 & 15.962 & 18.171 \\
\hline 3 & 16.467 & .283 & 15.889 & 17.045 \\
\hline 4 & 16.367 & .237 & 15.881 & 16.852 \\
\hline 5 & 17.533 & .406 & 16.703 & 18.364 \\
\hline
\end{tabular}

Figure 6 shows the students' generic skills, developed over time, in different patterns, before, during and after service-learning. Overall, there was an increase of students' generic skills, in terms of Adaptability Skills, Thinking Skills, Scholarship, Communication Skills, Teamwork Skills, and Global Citizen, throughout stage 1 until stage 5. As can be seen from the Adaptability Skills generic skills graph, there is a slight increase from Post-Adaptability 1 to Post-Adaptability 2. A similar scenario can be observed for Post Communication Skills 1 to Post-Communication Skills 2.

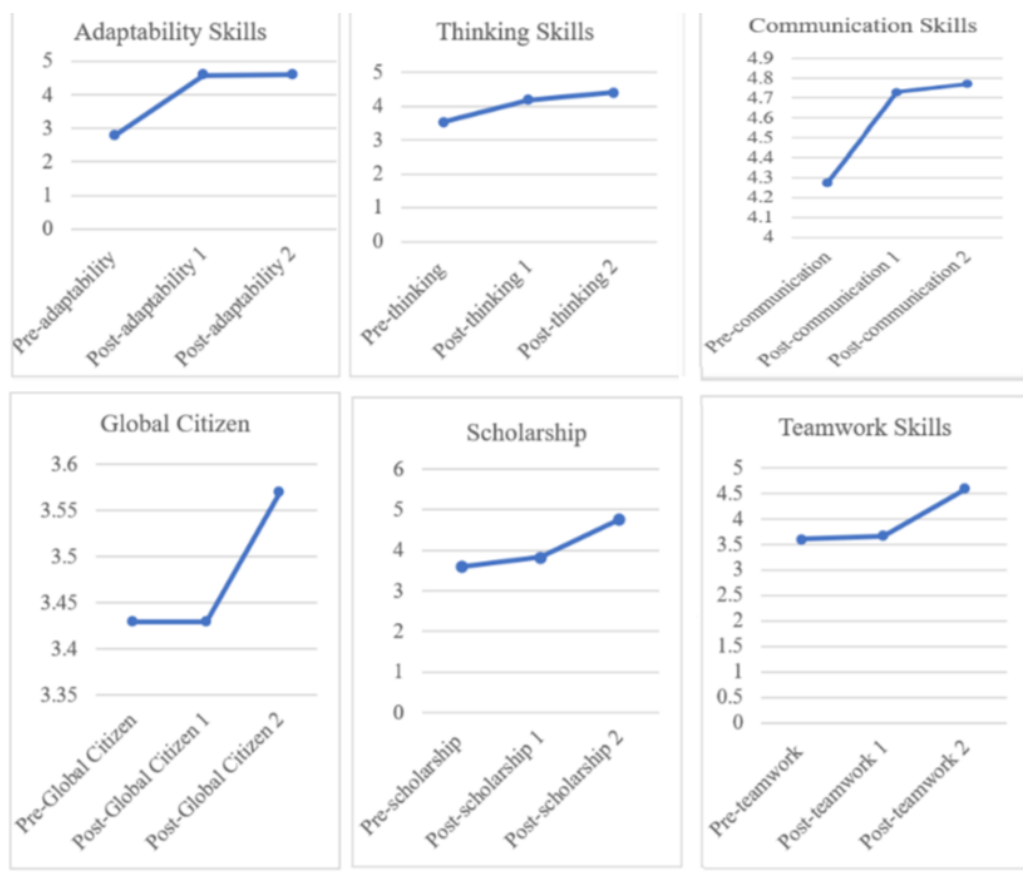

Fig. 6. Different Patterns of Students' Generic Skills 
As for Scholarship, there is a slight increase from Pre-Scholarship and Post-Scholarship 1, but there is a high increase in Post-Scholarship 2. Similarly, for Teamwork Skills, there is a slight increase from Pre-Teamwork Skills and Post-Teamwork Skills 1 , but there is a high increase in Post-Teamwork 2. However, for Thinking Skills, a gradual increase can be observed, from Pre-Thinking to Post-Thinking 2. Additionally, it was found that, students' Pre-Global Citizen and Post-Global Citizen 1 remain unchanged, but a rapid change occurs at Post-Global Citizen 2.

\section{Discussion}

For the first objective of this study, to determine the effect of integrating gamification in Hybrid Service-Learning (GAMYSEL) on student engagement, the students were found to be highly engaged in the application of gamification elements, which had them optimally involved in the learning activities, thus resulting in significant effects on their personal meaning and value in the completion of the given project, as described by [36]. Through the participation of students in the rewards system, students' engagement increased, proven by the majority of students who were in the category of Strategic Compliance and Optimal Engagement in each gamification elements, namely, points, badges, levels and leaderboards. Moreover, the rewards system proved to be effective in engaging students to gain the rewards offered in competing with their peers to gain points for online discussion, while also earning badges to commit themselves in their responsibilities, achieving levels to pass to the next part of the learning activities and competing in achieving leaderboards position. The GAMYSEL was made possible with the Learndash, BuddyBoss and GamiPress plugins, installed in WordPress, for interactive learning, reflective learning and to increase social instinct in an online learning environment. A previous research studied the potential of gamification elements to promote students' engagement [64]-[67] and proved its success in improving learning. In the present study, students were involved in the given tasks by the utilisation of gamification elements, and it was revealed that, this successfully resulted in their high engagements in learning. The present study also found that, levels had the most significant impact on students' learning engagement in their persistence to complete the given tasks. A levelling system has encouraged students to complete tasks and potentially increase their knowledge and connections with real-world problems. [68] asserted their belief that, a levelling system, tied with goal-settings, has the ability to demonstrate students' positive learning outcomes.

As for the second objective of this study, to improve the way students are engaged in learning to develop their generic skills, results of the pre-test, post-test 1 (intervention 1) and post-test 2 (intervention 2) showed greatly improved team effectiveness among the students, across a range of generic skills, including adaptability skills, teamwork skills, thinking skills, scholarship, communication skills and global citizen. [69] argued that, to be an effective team member, students should demonstrate some or many forms of these generic skills. The combination of points, badges, levels and leaderboards has resulted in students committing to work effectively in completing the Advocacy Hybrid Service-Learning project, while holding responsibilities and accountabilities, especially 
in serving the community. In this study, the integration of gamification elements was found to have kept students engaged throughout the learning process, in developing their generic skills. This was shown in the graphs in Figure 5, suggesting that, GAMYSEL had a positive impact on students' engagement and generic skills. The research revealed that, learners' experience in the use of GAMYSEL involves a certain degree of their engagement, that could be promoted in their generic skills development, through an Advocacy Hybrid Service-Learning approach.

\section{Conclusion}

The current study showed that, students' engagement provides opportunities for students to have active involvement in learning activities and relate their learning in real life situations, when collaborating with community partners. GAMYSEL was successful in encouraging students to have an active involvement with community partners, namely, community of experts, locality-based community and community in need in an Advocacy Hybrid Service-Learning approach. This study also proved Advocacy Hybrid Service-Learning as a service which provides a means for the community to experience a transfer of knowledge and skills, in addressing the community needs which involve the use of an online platform as a medium of service delivery to the community. The learning process was gamified from the online platform to engage students in Advocacy Hybrid-Service Learning in accomplishing the given project. By integrating gamification elements, students can become more active participants, in developing ways of thinking for discipline-specific knowledge and skills. This includes building culture of workplace practice within modes of skill development among students, namely, adaptability skills, thinking skills, scholarship, teamwork skills, communication skills and global citizen. Moreover, service-learning has bridged the gap between academic learning, online learning and the lack of essential workplace skills by providing experiential learning assessment in students' reflection activities [1], [4], [70]. Therefore, GAMYSEL has unleash the potentials of hybrid service learning and facilitate the development of generic skills, especially when the online platform makes use of Advocacy Hybrid Service-Learning approach. These potentials are in the forms of fostering knowledge retention, where participants were seen interacting with peers and community partners in ways that would be difficult to achieve in onsite and classroombased course, and broadening participation in community problem solving. GAMYSEL, therefore, offers innovative teaching and learning opportunities, which can enhance the students' service-learning experience, increase charitable, volunteer work and helps develop important academic skills required to build a better community. In conclusion, the findings of this research showed that, GAMYSEL provides a highly effective online platform for students to experience a transferable of knowledge and skills through their active participations, engagement and collaborations with the community. 


\section{Acknowledgement}

We would like to thank UTM Encouragement Research (UTMER) Grant, Universiti Teknologi Malaysia for sponsoring our work in Cost Center No. Q.J130000.3853. $18 \mathrm{~J} 82$ and Research Management Centre, Universiti Teknologi Malaysia for supporting the research grant for this study.

\section{References}

[1] R. R. Mcwhorter, J. A. Delello, and P. B. Roberts, "Giving Back: Exploring ServiceLearning in an Online Learning Environment," vol. 14, no. 2, pp. 80-99, 2016.

[2] B. Hasbún and F. Garcia, "Service-Learning as a Means to Promote Development of Social Responsibility Competency in a Department of Economics and Business (English translation)," Int. J. Res. Serv. Community Engagem., vol. 4, no. 1, 2016.

[3] K. Osman, "The inculcation of generic skills through service learning experience among science student teachers," Procedia - Soc. Behav. Sci., vol. 18, pp. 148-153, 2011, https://doi.org/10.1016/j.sbspro.2011.05.022

[4] A. Yusof, N. A. Atan, J. Harun, and M. Doulatabadi, "Developing students graduate attributes in service learning project through online platform," Proc. Int. Conf. Ind. Eng. Oper. Manag., vol. 2019, no. MAR, pp. 3524-3537, 2019.

[5] M. Salam, D. N. Awang Iskandar, D. H. A. Ibrahim, and M. S. Farooq, "Service learning in higher education: a systematic literature review," Asia Pacific Educ. Rev., vol. 20, no. 4, pp. 573-593, 2019, https://doi.org/10.1007/s12564-019-09580-6

[6] G. A. Gunter, "The effects of the impact of instructional immediacy on cognition and learning in online classes," Int. J. Soc. Sci., vol. 2, no. 3, pp. 196-202, 2007.

[7] A. P. Rovai and J. R. Downey, "Why some distance education programs fail while others succeed in a global environment," Internet High. Educ., vol. 13, no. 3, pp. 141-147, 2010, https://doi.org/10.1016/j.iheduc.2009.07.001

[8] A. Yusof, N. A. Atan, J. Harun, and M. Doulatabadi, "Understanding learners' persistence and engagement in Massive Open Online Courses: A critical review for Universiti Teknologi Malaysia," Man India, vol. 97, no. 12, pp. 147-157, 2017.

[9] C. Burgo, "Service-Learning for Students of Spanish: Promoting Civic Engagement and Social Justice through an Exchange Tutoring," Rev. Linguist. y Lenguas Apl., vol. 11, pp. 11-18, 2016, https://doi.org/10.4995/rlyla.2016.4133

[10] J. Eyler, "Creating Your Reflection Map," New Dir. High. Educ., vol. 2001, no. 114, p. 35, 2001, doi: 10.1002/he.11.abs.

[11] A. Yusof, N. A. Atan, J. Harun, and M. Doulatabadi, "Towards a conceptual framework for service-learning in online learning environment," Proc. Int. Conf. Ind. Eng. Oper. Manag., vol. 2018-March, no. January 2019, pp. 2893-2902, 2018.

[12] J. García-Gutiérrez, M. Ruiz-Corbella, and Á. Manjarrés Riesco, "Virtual Service-Learning in Higher Education. A Theoretical Framework for Enhancing its Development," Front. Educ., vol. 5, no. January, 2021, https://doi.org/10.3389/feduc.2020.630804

[13] Jean Strait and Katherine Nordyke, EService-learning: Creating Experiential Learning and Civic Engagement Through Online and Hybrid Courses, Illustrate. Stylus Publishing, 2015.

[14] Gregg Bennet \& Frederick Green, "Promoting Service Learning via Online Instruction," Coll. Stud. J., vol. 35(4), pp. 491-497, 2001, [Online]. Available: http://digitalcommons. unomaha.edu/cgi/viewcontent.cgi?article $=1016 \% 7 \mathrm{~B} \& \% 7 \mathrm{Dcontext}=$ slcehighered 
[15] J. Killian, "Pedagogical Experimentation: Combining Traditional, Distance, and Service Learning Techniques," J. Public Aff. Educ., vol. 10, no. 3, pp. 209-224, 2004, [Online]. Available: https://doi.org/10.1080/15236803.2004.12001360

[16] L. S. Waldner, M. C. Widener, and S. Y. McGorry, "E-Service Learning: The Evolution of Service-Learning to Engage a Growing Online Student Population," J. High. Educ. Outreach Engagem., vol. 16, no. 2, pp. 123-150, 2012, [Online]. Available: http:// openjournals.libs.uga.edu/index.php/jheoe/article/view/792

[17] MOE, "Malaysia Education Blueprint 2015-2025 (Higher Education)," Minist. Educ. Malaysia, vol. 2025, p. 40, 2015.

[18] I. Caponetto, J. Earp, and M. Ott, "Gamification and education: A literature review," Proc. Eur. Conf. Games-based Learn., vol. 1, no. October, pp. 50-57, 2014.

[19] S. De Sousa Borges, V. H. S. Durelli, H. M. Reis, and S. Isotani, "A systematic mapping on gamification applied to education," Proc. ACM Symp. Appl. Comput., no. March, pp. 216222, 2014, https://doi.org/10.1145/2554850.2554956

[20] J. Schwehm and T. \& E. O. Lasker-Scott, "A comparison of learning outcomes for adult students in on-site and online service-learning," Online J. Distance Learn. Adm., vol. 20, no. 1, pp. 1-17, 2017, [Online]. Available: http://search.ebscohost.com/login.aspx?direct $=$ true $\& \mathrm{db}=$ eue $\& A N=121985880 \&$ site $=$ ehost-live

[21] J. M. Denstadli, T. E. Julsrud, and R. J. Hjorthol, "Videoconferencing as a mode of communication: A comparative study of the use of Videoconferencing and face-to-face meetings," J. Bus. Tech. Commun., vol. 26, no. 1, pp. 65-91, 2012, https://doi.org/ $\underline{10.1177 / 1050651911421125}$

[22] K. Haman, "Mastering the Virtual Practice: Virtual vs. Face-to-Face Meetings," 2020. https://www.alliancebernstein.com/library/Mastering-the-Virtual-Practice-Virtual-vs-Faceto-Face-Meetings.htm (accessed Jun. 02, 2021). https://doi.org/10.24875/recice.m20000183

[23] M. Andrew, Game Thinking. 2015.

[24] R. G. Bringle and J. A. Hatcher, "Implementing Service Learning in Higher Education," J. Higher Educ., vol. 67, no. 2, pp. 221-239, 1996, https://doi.org/10.1080/00221546 .1996 .11780257

[25] WorldEconomicForum, "The 10 skills you need to thrive in the Fourth Industrial Revolution." 2020, [Online]. Available: https://www.weforum.org/agenda/2016/01/the-10skills-you-need-to-thrive-in-the-fourth-industrial-revolution/

[26] F. Martin and J. Ertzberger, "Here and now mobile learning: An experimental study on the use of mobile technology," Comput. Educ., vol. 68, pp. 76-85, 2013, https://doi.org/ 10.1016/j.compedu.2013.04.021

[27] H. T. T. Nguyen, "Communication skills and reflection practice in smart english teaching and learning environment a case study," Int. J. Emerg. Technol. Learn., vol. 15, no. 17, pp. 221-237, 2020, https://doi.org/10.3991/ijet.v15i17.15235

[28] E. M. Boyd and A. W. Fales, "Reflective learning: Key to learning from experience," $J$. Humanist. Psychol., vol. 23, no. 2, pp. 99-117, 1983.

[29] A. Brockbank and I. McGill, Facilitating reflective learning in higher education. McGrawHill Education (UK), 2007.

[30] L. Finlay, "Reflecting on 'Reflective practice,"” no. January, pp. 1-27, 2008, https://doi.org/ 10.1016/0260-4779(91)90031-R

[31] B. L. Cameron and A. M. Mitchell, "Reflective peer journals: developing authentic nurses," J. Adv. Nurs., vol. 18, no. 2, pp. 290-297, 1993. https://doi.org/10.1046/j.1365-2648. $\underline{\text { 1993.18020290.x }}$ 
[32] K. L. Guthrie and H. McCracken, "Reflection: the importance of making meaning in eservice-learning courses," J. Comput. High. Educ., vol. 26, no. 3, pp. 238-252, 2014, https://doi.org/10.1007/s12528-014-9087-9

[33] A. W. Astin, "Student involvement: A developmental theory for higher education," Coll. Student Dev. Acad. Life Psychol. Intellectual, Soc. Moral Issues, no. July, pp. 251-263, 2014.

[34] F. Newmann, G. Wehlage, and S. Lamborn, The significance and sources of student engagement, no. 7. 1992.

[35] R. S. Alsawaier, "The effect of gamification on motivation and engagement," Int. J. Inf. Learn. Technol., vol. 35, no. 1, pp. 56-79, 2017, https://doi.org/10.1108/ijilt-02-2017-0009

[36] P. C. Schlechty, Engaging students: The next level of working on the work. John Wiley \& Sons, 2011.

[37] Y. Samur, "Measuring engagement effects of educational games and virtual manipulatives on mathematics," Diss. Submitt. to Fac. Virginia Polytech. Inst. State Univ. Partial fulfillment Requir. degree Dr. Philos. Curric. Instr., pp. 1-258, 2012.

[38] V. Sagayadevan and S. Jeyaraj, "The role of emotional engagement in lecturer-student interaction and the impact on academic outcomes of student achievement and learning," vol. 12, no. September 2012, pp. 1-30, 2009.

[39] A. Domínguez, J. Saenz-De-Navarrete, L. De-Marcos, L. Fernández-Sanz, C. Pagés, and J. J. Martínez-Herráiz, "Gamifying learning experiences: Practical implications and outcomes," Comput. Educ., vol. 63, pp. 380-392, 2013, https://doi.org/10.1016/j.compedu. $\underline{2012.12 .020}$

[40] G. Zichermann and C. Cunningham, Gamification by design: Implementing game mechanics in web and mobile apps. "O'Reilly Media, Inc.," 2011.

[41] M. Man, M. H. N. Azhan, and W. M. A. F. Wan Hamzah, "Conceptual model for profiling student behavior experience in e-Learning," Int. J. Emerg. Technol. Learn., vol. 14, no. 21, pp. 163-175, 2019, https://doi.org/10.3991/ijet.v14i21.10936

[42] S. Deterding, D. Dixon, R. Khaled, and L. Nacke, "From game design elements to gamefulness," Proc. 15th Int. Acad. MindTrek Conf. Envisioning Futur. Media Environ. MindTrek '11, no. March 2014, p. 9, 2011, https://doi.org/10.1145/2181037.2181040

[43] K. M. Kapp, The gamification of learning and instruction: game-based methods and strategies for training and education. John Wiley \& Sons, 2012.

[44] K. Duggan and K. Shoup, Business gamification for dummies. John Wiley \& Sons, 2013.

[45] J. Maan, "Social Business Transformation through Gamification," Int. J. Manag. Inf. Technol., vol. 5, no. 6, pp. 9-16, 2013, https://doi.org/10.5121/ijmit.2013.5302

[46] E. Chapman, "Alternative approaches to assessing student engagement rates," Pract. Assessment, Res. Eval., vol. 8, no. 13, pp. 2002-2003, 2003.

[47] S. R. Jimerson, E. Campos, and J. L. Greif, "Toward an Understanding of Definitions and Measures of School Engagement and Related Terms," Calif. Sch. Psychol., vol. 8, no. 1, pp. 7-27, 2003, https://doi.org/10.1007/bf03340893

[48] E. A. Skinner, J. G. Wellborn, and J. P. Connell, "What It Takes to Do Well in School and Whether I've Got It: A Process Model of Perceived Control and Children's Engagement and Achievement in School," J. Educ. Psychol., vol. 82, no. 1, pp. 22-32, 1990, https://doi.org/ 10.1037/0022-0663.82.1.22

[49] M. Romero, "Learner Engagement in the use of Individual and Collaborative Serious Games," in Increasing Student Engagement and Retention Using Immersive Interfaces: Virtual Worlds, Gaming, and Simulation, 2015, pp. 15-34. https://doi.org/10.1108/s2044$\underline{9968(2012) 000006 \mathrm{c} 004}$ 
[50] R. M. Carini, G. D. Kuh, and S. P. Klein, "Student engagement and student learning: Testing the linkages," Res. High. Educ., vol. 47, no. 1, pp. 1-32, 2006, https://doi.org/10.1007/ s11162-005-8150-9

[51] C. Silpasuwanchai, X. Ma, H. Shigemasu, and X. Ren, "Developing a Comprehensive Engagement Framework of Gamifcation for Reflective Learning," Proc. 2016 ACM Conf. Des. Interact. Syst., pp. 459-472, 2016, https://doi.org/10.1145/2901790.2901836

[52] J. A. Fredricks, P. C. Blumenfeld, and A. H. Paris, "School Engagement: Potential of the Concept, State of the Evidence," Rev. Educ. Res., vol. 74, no. 1, pp. 59-109, Mar. 2004, https://doi.org/10.3102/00346543074001059

[53] R. P. Adler and J. Goggin, "What Do We Mean By 'Civic Engagement'?," J. Transform. Educ., vol. 3, no. 3, pp. 236-253, 2005, https://doi.org/10.1177/1541344605276792

[54] J. Gibb, Generic skills in Vocational Education and Training: Research Readings, Australian. National Centre for Vocational Education Research Ltd, 2004.

[55] J. A. Bringle, R.G and Hatcher, "Reflection in Service Learning: Making Meaning of Experience," Educational. Horizons, vol. 77, no. Summer. pp. 179-185, 1999.

[56] MOE, "The SULAM Initiative Translates University Concepts For The Community," Kementerian Pendidikan Malaysia, Apr. 19, 2019. https://www.moe.gov.my/en/ menumedia/electronic-media/news-and-activities/sulam-2019 (accessed Jun. 02, 2021).

[57] MOE, "SULAM INFORMATION," Kementerian Pendidikan Malaysia, 2019. https:// sulam.mohe.gov.my/web/index.php?fle=info (accessed Jun. 02, 2021).

[58] UTMi-League, "Service Learning Malaysia, University for Society," 2020. https:// ileague.utm.my/sulam-2/ (accessed Jun. 02, 2021).

[59] C. B. Kaye, The complete guide to service learning: Proven, practical ways to engage students in civic responsibility, academic curriculum, \& social action. Free Spirit Publishing, 2004.

[60] M. Barnett, P. T. Silver, and T. S. Grundy, "Implementing Service-Learning Pedagogy: A Case Example," J. High. Educ. Outreach Engagem., vol. 13, no. 4, pp. 117-134, 2009.

[61] S. D. G. SDG, "Sustainable Development Goals.pdf," Sustainable Development Goals: Guidelines For The Use of The SDG Logo Including The Colour Wheel, And 17 Icons, 2015. https://www.un.org/sustainabledevelopment/wp-content/uploads/2019/01/SDG_Guidelines AUG_2019_Final.pdf (accessed Jun. 02, 2021).

[62] UTMi-League, "Generic Skills Measurement," Generic Skills in Universiti Teknologi Malaysia, 2017. https://ileague.utm.my/generic-skills/ (accessed Jun. 02, 2021).

[63] V. J. Caracelli and J. C. Greene, "Data Analysis Strategies for Mixed-Method Evaluation Designs," Educ. Eval. Policy Anal., vol. 15, no. 2, pp. 195-207, Aug. 1993, https://doi.org/ $10.3102 / 01623737015002195$

[64] M. Cronk, "Using gamification to increase student engagement and participation in class discussion," in EdMedia + Innovate Learning, 2012, pp. 311-315.

[65] L. Ding, C. Kim, and M. Orey, "Studies of student engagement in gamified online discussions," Comput. Educ., 2017, https://doi.org/10.1016/j.compedu.2017.06.016

[66] I. Bouchrika, N. Harrati, V. Wanick, and G. Wills, "Exploring the impact of gamification on student engagement and involvement with e-learning systems," Interact. Learn. Environ., pp. 1-14, 2019. https://doi.org/10.1080/10494820.2019.1623267

[67] F. J. Liu and C. M. Lu, "Design and Implementation of a Collaborative Educational Gamification Authoring System,” Int. J. Emerg. Technol. Learn., vol. 16, no. 17, pp. 277289, 2021, https://doi.org/10.3991/ijet.v16i17.24087

[68] E. Mekler, F. Brühlmann, K. Opwis, and A. Tuch, "Do points, levels and leaderboards harm intrinsic motivation? An empirical analysis of common gamification elements," $A C M$ 
Paper-Students Engagement and Development of Generic Skills in Gamified Hybrid Service-Learning...

International Conference Proceeding Series. 2013. https://doi.org/10.1145/2583008. $\underline{2583017}$

[69] P. Watson, "Innovative teaching, teamwork and generic skills in the university environment," Celebr. Teach. Macquarie, no. Macquarie University, NSW, 28-29 November, 2002. North Ryde, NSW.: Macquarie University, 2002. https://doi.org/10. 21475/ajcs.2016.10.11.pne46

[70] J. A. Hatcher and R. G. Bringle, "Reflection: Bridging the Gap between Service and Learning," Coll. Teach., vol. 45, no. 4, pp. 153-158, 1997, https://doi.org/10.1080/87567 $\underline{559709596221}$

\section{Authors}

Azizah Yusof is a research fellow with the Faculty of Social Sciences and Humanities, Universiti Teknologi Malaysia (UTM). She obtained her MEd. (Educational Technology) and Bsc. in Computer Science with Education (Mathematics) from UTM. She holds a Microsoft Certified Systems Engineer (MCSE) certificate and has taught ICTrelated subjects for co-curriculum courses for UTM Institute for Life-Ready Graduates.

Noor Azean Atan is an Associate Professor in Faculty of Social Sciences and Humanities, UTM. She received her PhD in Educational Technology from the Faculty of Education, UTM, Msc (Information Technology) from Universiti Teknologi MARA and Bsc Computer Science from the Faculty of Computer Science and Information Technology, UTM.

Jamalludin Harun is an Associate Professor in Faculty of Social Sciences and Humanities, UTM. He obtained his first degree, BSc. Computer with Education (Chemistry) (Hons.) from UTM (1995), MEd. (Educational Media and Computers) from Arizona State University, USA (1998), and PhD (Educational Technology) from Universiti Teknologi Malaysia (2003).

Mohd Shafie Rosli is a senior lecturer in Faculty of Social Sciences and Humanities, UTM and received his $\mathrm{PhD}$ in Educational Technology from the Faculty of Social Sciences and Humanities, UTM.

Umi Mastura Abd Majid is a research fellow with the Faculty of Social Sciences and Humanities, UTM and holds a Bsc. in Computer Science (Graphic and Multimedia Software) and MEd. (Educational Technology) from UTM.

Article submitted 2021-09-11. Resubmitted 2021-10-30. Final acceptance 2021-11-01. Final version published as submitted by the authors. 